九州大学学術情報リポジトリ

Kyushu University Institutional Repository

\title{
Storage of Litchi Fruits at Room Temperature with Use of Leaf Extract of Japanese Cypress (Platycladus orientalis)
}

Yang, Shang-Dong

College of Agriculture, Guangxi University

Huang, Cheng-Ge

Agricultural Bureau of Baise City

Long, Ming-Hua

College of Agriculture, Guangxi University

Tang, Zhi-Peng

College of Agriculture, Guangxi University

他

https://doi.org/10.5109/10086

出版情報: 九州大学大学院農学研究院紀要. 53 (1)，pp. 149-153，2008-02-28. Faculty of Agriculture, Kyushu University

バージョン :

権利関係 : 


\title{
Storage of Litchi Fruits at Room Temperature with Use of Leaf Extract of Japanese Cypress (Platycladus orientalis)
}

\author{
Shang-Dong YANG ${ }^{1}$, Cheng-Ge HUANG ${ }^{2}$, Ming-Hua LONG ${ }^{1}$, \\ Zhi-Peng TANG ${ }^{1}$ and Kazuhiko EGASHIRA*
}

\author{
Laboratory of Soil Science, Division of Soil Science and Plant Production, \\ Department of Plant Resources, Faculty of Agriculture, \\ Kyushu University, Fukuoka 812-8581, Japan \\ (Received November 9, 2007 and accepted November 30, 2007)
}

\begin{abstract}
Japanese cypress was tested for the safe storage of litchi fruits at room temperature on inhibiting mold development on litchi pericarp, keeping litchi taste and preventing from browning. The extract of Japanese cypress (Platycladus orientalis) obtained by the squeezing method was found to be more effective than the extract by the boiling method on the inhibiting effect on the development of mold on the pericarp surface. However, the water extract of Japanese cypress by the two methods showed the effects similar to water on keeping litchi taste and preventing from browning. It was indicated that use of only Japanese cypress was not suitable to the safe storage of litchi fruits at room temperature.
\end{abstract}

\section{INTRODUCTION}

Litchi (Litchi chinensis Sonn.) is a typical subtropical fruit which belongs to the Sapindaceae family and has been planted for more than 2,000 years in China. Litchi has pericarp of brightly red color and white and transparent sarcocarp rich in sweet juice, and can be called the most tasteful fruit in the sub-tropical zone. The effect of litchi on anti-oxidizing and preventing human being from senility by containing plenty of nutrients in sarcocarp, such as carbohydrate, vitamin and mineral nutrients of calcium and phosphorus, has been reported (Wu et al., 2004). In addition, physiologically active substances of phenol, anthocyanin and flavonoids are plentiful in pericarp and seed of litchi and effective in lowering the blood-sugar level and inhibiting disease of hepatitis (Dong et al., 2005). Litchi is becoming more popular to consumers for relieving a health problem.

Nowadays, the cultivation area and production of litchi in China are highest in the world. Guangxi Zhuang Autonomous Province (abbreviated as Guangxi thereafter) is the second highest in the production scale in China, following Guangdong Province. The cultivation area and production of litchi in Guangxi reached to 222.1 thousands ha and 370.5 thousands tons, respectively, in 2004, and increased by 16.5 thousands ha and 189.2 thousands tons, respectively, compared with those in 2000 (Tang et al., 2006). Litchi production will be more developed in near future in Guangxi owing to the increasing international trade and economical development in China.

However, the maturation period of litchi is in the hot summer days and the harvesting time is restricted to a

\footnotetext{
1 Laboratory of Horticulture Science, Division of Horticulture Science and Plant Production, College of Agriculture, Guangxi University, Nanning, Guangxi Province, China 53004; E-mail address of the top author: yangshangdong@hotmail.com

2 Agricultural Bureau of Baise City, Guangxi Province, China 533000

* Corresponding author (E-mail: kegashi@agr.kyushu-u.ac.jp)
}

short period, and it has a characteristic stated as "color changes within one day, odor loses within two days and taste turns bad within three days after harvest" due to its vigorous physiological activity and high air temperature. According to the statistical data (Lu, 1998), loss of litchi fruits by rot reaches to $20 \%$ of the total production every year. It is becoming a main limiting factor to increase in the litchi production.

Methods for storage of litchi fruits have been studied by a lot of researchers (Lai and Ao, 1998). Rot of litchi fruits is mainly induced by 14 kinds of fungi, such as Aspergillus niger, Aspergillus flavus, and Penicillium sp., and a few kinds of yeast and bacteria (Zhang et al., 2004). Usually, infection by these germs occurs at the times of pre-harvest, in-harvest and post-harvest during storage, and in transportation and sale, and rot is developed depending on the varieties and physiological status of litchi under special conditions. In addition to rot by germs, anthocyanin and polyphenol oxidase (abbreviated as PPO thereafter) abundant in pericarp of litchi have a function to make pericarp browning (Zhang et al., 2004).

At present, the most popularly used ways for storage of litchi fruits are low temperature, addition of a chemical agent, fumigating with $\mathrm{SO}_{2}$, air control and radiation (Xie, 2007), and the storage at low temperature is recognized as the most efficient way (Pang and Zhang, 2001). However, browning of litchi fruits after storage is fast in the storage at low-temperature compared with the storage at room temperature, and as a result the time for sale is shortened. The method of air control needs special equipment and is not easy for operation in production areas. The other methods of using a chemical agent or radiation and fumigating with $\mathrm{SO}_{2}$ will be limited in future due to risk of the harmful remnants to human health.

Since there are some difficulties in the presently used methods, as stated in the above, research was started on the healthy and convenient method to store litchi fruits at room temperature with use of natural herbs, 
such as sessile stemona root, ginger, Japanese fleece flower rhizome and clove (Chen, 2005). Leaves of Japanese cypress not only have been used as a styptic in days but also can be used to inhibit growth of bacteria (Wang, 1983; Liu et al., 1995). A lot of Japanese cypress (Platycladus orientalis) is planting in Guangxi, but its utilization for storing litchi fruits has not been reported. The aim of the present study was to explore the potential use of Japanese cypress as a material for storing litchi fruits safely at room temperature.

\section{MATERIALS AND METHODS}

\section{Materials \\ Litchi}

'Linshanxiangli' was used as a test variety of litchi, and the test was carried out during the days of June to August in 2006 and 2007. Litchi fruits of the same size and maturity were harvested from a litchi tree in the orchard of Guangxi University. They were quickly brought back to the laboratory, immersed in ice-water $\left(0 \sim 5^{\circ} \mathrm{C}\right)$ for 5 minutes after washing with tap water cleanly, and dried naturally at room temperature.

Japanese cypress and extraction

Fresh leaves of Japanese cypress without damage by disease and pest were picked off in the campus of Guangxi University. After quickly brought back to the laboratory, leaves were washed with tap water cleanly and dried at room temperature, and subjected to extraction as follows:

(1) Extraction by the squeezing method: leaves were cut into pieces with a scissors, mixed with distilled water with a weight ratio of $1: 2$ of leaves:water, squeezed with a mixer for 10 minutes, and filtered to get the filtrate which was named as the extract A.

(2) Extraction by the boiling method: leaves were put into a pot with distilled water with a weight ratio of 1:2 of leaves:water, boiled for 45 minutes with keeping the volume of water by constant filling up, and filtered to get the filtrate which was named as the extract $B$.

Chemical storage agent

45\% Sportak, bought in market, was used as a chemical storage agent. Its main component was prochloraz. Ethylene absorbent

Activated carbon, bought in market, was used as an absorbent of ethylene. Ten $g$ of activated carbon was packed into a small, poromeric bag like a little tea bag, and put into a plastic bag with litchi fruits when packing in the test.

\section{Treatments on storage of litchi fruits}

The following 4 treatments were tested on storage of litchi fruits:

Treatment CK: use of distilled water as control;

Treatment II : use of a chemical storage agent of 45\% Sportak diluted to 500 times with distilled water just before test, according to the instruction manual;
Treatment III: use of the extract A;

Treatment IV: use of the extract B.

Forty-five litchi fruits of the same size were selected, put in a net, and dipped into the treatment liquid for one minute. After drying at room temperature, they were put into a plastic bag together with an ethyleneabsorbent bag and stood at room temperature of $29 \pm 3{ }^{\circ} \mathrm{C}$ under humidity of $80 \sim 85 \%$. The treatment was done in triplicate.

\section{Observation of apparent changes in litchi fruits during storage}

Development of mold on litchi fruits

Occurrence of mold on the pericarp surface was observed regularly every day to count the number of moldy fruits.

Browning of litchi fruits

The commercial-goods rate of fruits was calculated and divided into 5 levels according to the method described by Liang et al. (1998). That is, the first level (I): pericarp of red color without any browning; the second level (II): pericarp of red color with browning of a diameter below $0.5 \mathrm{~cm}$; the third level (III): pericarp of red color with browning of a diameter of $0.5 \sim 1 \mathrm{~cm}$; the fourth level (IV): pericarp of lightly red color without luster and with browning of a diameter over $1.5 \mathrm{~cm}$; the fifth level (V): pericarp with browning of more than 50\%. The commercial-goods rate of fruits was calculated by the following formula.

Commercial-goods rate $(\%)=100$ (number of the firstlevel fruits + number of the second-level fruits)/ (total number of fruits)

Weight loss of litchi fruits

The weight loss of litchi fruits was assessed by the method described by Xie et al. (2001). Weight of fruits in a plastic bag was measured regularly every day, and the rate of weight loss was calculated by the following formula.

Weight-loss rate (\%)=100 (weight before storage - weight after storage)/(weight before storage)

\section{Measurement of the content of components con- trolling the taste of litchi fruits}

Ten fruits were taken out from the plastic bag in each treatment. After removal of pericarp and seed, the flesh was subjected to squeezing with a squeezer.

The titratable acid content was measured by the neutralizing method of titration with $0.1 \mathrm{M} \mathrm{NaOH}$. The content of total soluble solid (abbreviated as TSS thereafter) in litchi fruits was measured by the ABBE refractometer method.

\section{Measurement of the PPO activity and anthocyanin content in litchi pericarp on browning PPO activity}

The PPO activity was measured by the method described by Tian et al. (2006). Ten fruits were taken 
out randomly from the plastic bag in each treatment, and pericarp was peeled off as a sample. One g of finely cut pericarp was put into a cooled mortar with $1 \mathrm{~g}$ of quartz sand and $10 \mathrm{ml}$ of phosphate-citrate buffer $(\mathrm{pH} \mathrm{7.0)}$ and ground until getting supernatant. The mixture was then centrifuged at 9,000 rpm under low temperature for 10 minutes. The supernatant was stored at $0 \sim 4{ }^{\circ} \mathrm{C}$ for analysis.

In the enzymatic reaction, $3 \mathrm{ml}$ of $0.025 \mathrm{~mol} / \mathrm{L}$ potassium phosphate buffer ( $\mathrm{pH} 7.0$ ), $0.015 \mathrm{~mol} / \mathrm{L}$ catechol solution, and $0.6 \mathrm{ml}$ of the supernatant from litchi pericarp were put into a beaker in order and incubated in a water bath controlled at $30^{\circ} \mathrm{C}$ for 15 minutes. After reaction absorbance was measured at $398 \mathrm{~nm}$.

\section{Anthocyanin content}

The anthocyanin content in litchi pericarp was measured by the method described by $\mathrm{Hu}$ et al. (2004). Ten fruits were taken out randomly from the plastic bag in each treatment, and pericarp was peeled off as a sample. Pericarp was cut finely and immersed into $1 \% \mathrm{HCl}$ solution until the color of pericarp was faded away, followed by filling up to $100 \mathrm{ml}$ after filtration. One $\mathrm{ml}$ of the filtrate was diluted to $5 \mathrm{ml}$ by addition of each $2 \mathrm{ml}$ of $0.4 \mathrm{~mol} / \mathrm{L} \mathrm{KCl-HCl}$ solution $(\mathrm{pH} 1.0)$ and $0.4 \mathrm{~mol} / \mathrm{L}$ citrate-disodium phosphate buffer ( $\mathrm{pH}$ 5.0). Absorbance was measured at $510 \mathrm{~nm}$ after mixing thoroughly. Distilled water was used as the control with the same operation as above.

\section{RESULTS AND DISCUSSION}

\section{Effects of different treatments on apparent chang- es in litchi fruits during storage}

Development of mold on litchi fruits

As shown in Table 1, the number of moldy fruits was nothing at 1 day after treatment but temporarily increased in every treatment when stored at room temperature. The number of moldy fruits under treatments with the chemical agent and the Japanese cypress extract was smaller than that of the control at 4 and 7 days after treatment. Among the chemical and biological treatments, the chemical agent and extract A inhibited development of mold on the pericarp surface at 4 and 7 days after treatment compared with the control at the $5 \%$ significant level. However, no significant difference from the control was found to the extract B. It suggests that the inhibiting effect is more effective for the squeezing method (extract A) than for the boiling method (extract B) in the extraction from Japanese cypress, although the difference between the two methods was not significant. The number of moldy fruits became significantly smaller for the chemical agent than for the extracts A and B at 7 days after treatment, suggesting the relatively quick loss of the inhibiting function of the extract from Japanese cypress.

Browning and weight loss of litchi fruits

Table 2 shows temporal changes in the commercialgoods and weight-loss rates under different treatments when stored at room temperature. Both rates were $100 \%$ or $0 \%$ at 1 day after treatment irrespective of the treatment and temporarily decreased or increased in every treatment. The most effective treatment to keep the commercial-goods rate was found to the chemical agent, followed by the extracts $\mathrm{A}$ and $\mathrm{B}$, similar to the inhibiting effect on the development of mold on the preicarp surface. The commercial-goods rate for the extracts A and B was higher than that for the control at 4 and 7 days after treatment, but there was observed insignificant difference between them. The chemical agent significantly suppressed the decrease in the commercial-goods rate with time. Even in this case, the commercial-goods rate was reduced to $20 \%$ at 7 days after treatment. The weight-loss rate under the treatments with the chemical agent and extracts A and B was lower than that for the control. However, no significant difference in the weight-loss rate was noticed among the 4 treatments, indicating that chemical and biological treatments hardly affect suppress of the weight loss from litchi fruits.

Table 1. Temporal changes in the number of moldy fruits under different treatments when stored at room temperature

\begin{tabular}{lccc}
\hline & \multicolumn{3}{c}{ Number of moldy fruits } \\
\cline { 2 - 4 } Treatment & $\begin{array}{c}\text { One day after } \\
\text { treatment }\end{array}$ & $\begin{array}{c}\text { Four days after } \\
\text { treatment }\end{array}$ & $\begin{array}{c}\text { Seven days } \\
\text { after treatment }\end{array}$ \\
\hline Control & 0 & $18.6 \mathrm{a}$ & $28.3 \mathrm{a}$ \\
Chemical agent & 0 & $11.7 \mathrm{c}$ & $22.0 \mathrm{c}$ \\
Extract A & 0 & $14.3 \mathrm{bc}$ & $25.3 \mathrm{~b}$ \\
Extract B & 0 & $16.3 \mathrm{ab}$ & $26.3 \mathrm{ab}$ \\
\hline
\end{tabular}

Different alphabets mean statistical difference at the $5 \%$ level.

Table 2. Temporal changes in the commercial-goods and weight-loss rates of litchi fruits under different treatments when stored at room temperature

\begin{tabular}{|c|c|c|c|c|c|c|}
\hline Treatment & \multicolumn{2}{|c|}{ One day after treatment } & \multicolumn{2}{|c|}{ Four days after treatment } & \multicolumn{2}{|c|}{ Seven days after treatment } \\
\hline Control & 100 & 0 & $36.2 \mathrm{~b}$ & $3.3 \mathrm{a}$ & $3.8 \mathrm{~b}$ & $5.1 \mathrm{a}$ \\
\hline Extract B & 100 & 0 & $37.4 \mathrm{~b}$ & $2.4 \mathrm{a}$ & $7.9 \mathrm{~b}$ & $4.2 \mathrm{a}$ \\
\hline
\end{tabular}

Different alphabets mean statistical difference at the $5 \%$ level. 
As factors of browning of litchi fruits, $\mathrm{Hu}$ and Ning (2001) reported water loss from fruits, water stress, the anthocynin content and PPO activity in pericarp, and destruction of vacuole and cell membrane. According to the above results in the present study, effects of the Japanese cypress extract on those factors are considered to be small except the effect on the water loss. The effect on the prevention of water loss may be a reason for the somewhat higher but insignificantly different commercial-goods rate for the extract from Japanese cypress than for water (control).

\section{Effects of different treatments on the content of components controlling the taste of litchi fruits}

As shown in Table 3, the contents of titratable acid and TSS controlling the taste of litchi fruits were not significantly different among the 4 treatments until 7 days after treatment. Meanwhile, the contents of both components gradually decreased with time in every treatment, similar to the results of Chen et al. (2004) under storage at room temperature for 3 days. Xie et al. (2001) reported that litchi fruits continued respiration after harvest and that a part of sugar and organic acid of metabolites in fruits was consumed for their own respiration. Based on the above thing, it was indicated that the chemical storage agent of $45 \%$ Sportak and the Japanese cypress extract has no controlling effect on the respiration of litchi fruits after harvest, showing the similar tendency to the previous study (Xie et al., 2001).

Effects of different treatments on the PPO activity and the anthocyanin content in litchi pericarp on browning

It has been understood that browning of litchi peri- carp is affected by many factors and that especially the coloring reactions involved by many components are catalyzed by PPO in pericarp (Chen et al., 2004). As shown in Table 4, the PPO activity increased continuously in every treatment until 7 days after treatment, corresponding with the temporal decrease in the commercial-goods rate (Table 2). The PPO activity was always lower for the treatments with the chemical agent and extracts $\mathrm{A}$ and $\mathrm{B}$ than for the control at 4 and 7 days after treatment, but there was observed no significant difference between them. Temporal decrease in the commercial-goods rate caused by development of browning was significantly suppressed by the treatment with the chemical agent (Table 2). However, it was not consistent with the result of the PPO activity measurement.

Anthocyanin is a main pigment in litchi pericarp and is an important substance for browning by its decomposition (Xu et al., 2004). As shown in Table 4, the content of anthocyanin in litchi pericarp decreased gradually with time until 7 days after treatment, similar to the report on 'Nomici' variety by Xu et al. (2005). However, the anthocyanin content was not significantly different among the 4 treatment at any days after treatment, indicating that the chemical storage agent of $45 \%$ Sportak and the Japanese cypress extract has no clear effect on suppress of the decomposition of anthocyanin.

Based on the above results, it is suggested that browning of litchi pericarp can not be delayed by the treatment only with Sportak or the extract from Japanese cypress. Further studies are needed to look for an appropriate method or compound to prevent litchi pericarp from browning.

Table 3. Effects of different treatments on the contents of titratable acid and TSS of litchi fruits under storage at room temperature

\begin{tabular}{|c|c|c|c|c|c|c|}
\hline Treatment & \multicolumn{2}{|c|}{ One day after treatment } & \multicolumn{2}{|c|}{ Four days after treatment } & \multicolumn{2}{|c|}{ Seven days after treatment } \\
\hline Control & $0.72 \mathrm{a}$ & $16.2 \mathrm{a}$ & $0.66 \mathrm{a}$ & $15.3 \mathrm{a}$ & $0.63 \mathrm{a}$ & $15.2 \mathrm{a}$ \\
\hline Chemical agent & $0.69 \mathrm{a}$ & $16.5 \mathrm{a}$ & $0.65 \mathrm{a}$ & $15.8 \mathrm{a}$ & $0.62 \mathrm{a}$ & $15.5 \mathrm{a}$ \\
\hline Extract A & $0.67 \mathrm{a}$ & $16.2 \mathrm{a}$ & $0.64 \mathrm{a}$ & $15.6 \mathrm{a}$ & $0.59 \mathrm{a}$ & $15.3 \mathrm{a}$ \\
\hline
\end{tabular}

Different alphabets mean statistical difference at the $5 \%$ level.

Table 4. Effects of different treatments on the PPO activity and anthocyanin content in litchi pericarp under storage at room temperature

\begin{tabular}{|c|c|c|c|c|c|c|}
\hline \multirow[b]{2}{*}{ Treatment } & \multicolumn{2}{|c|}{ One day after treatment } & \multicolumn{2}{|c|}{ Four days after treatment } & \multicolumn{2}{|c|}{ Seven days after treatment } \\
\hline & $\begin{array}{l}\text { PPO activity } \\
\text { (U/g/min) }\end{array}$ & $\begin{array}{l}\text { Anthocynin content } \\
\text { (U/g) (FW) }\end{array}$ & $\begin{array}{l}\text { PPO activity } \\
\text { (U/g/min) }\end{array}$ & $\begin{array}{l}\text { Anthocynin content } \\
\text { (U/g) (FW) }\end{array}$ & $\begin{array}{l}\text { PPO activity } \\
\text { (U/g/min) }\end{array}$ & $\begin{array}{c}\text { Anthocynin content } \\
\text { (U/g) (FW) }\end{array}$ \\
\hline Control & $50.1 \mathrm{a}$ & $7.01 \mathrm{a}$ & $56.3 \mathrm{a}$ & $6.35 \mathrm{a}$ & $62.2 \mathrm{a}$ & $6.06 \mathrm{a}$ \\
\hline Chemical agent & $50.5 \mathrm{a}$ & $7.05 \mathrm{a}$ & $54.6 \mathrm{a}$ & $6.43 \mathrm{a}$ & $59.7 \mathrm{a}$ & $6.18 \mathrm{a}$ \\
\hline Extract A & $50.8 \mathrm{a}$ & $7.12 \mathrm{a}$ & $53.7 \mathrm{a}$ & $6.41 \mathrm{a}$ & $57.6 \mathrm{a}$ & $6.22 \mathrm{a}$ \\
\hline Extract B & $51.2 \mathrm{a}$ & $7.03 \mathrm{a}$ & $54.1 \mathrm{a}$ & $6.29 \mathrm{a}$ & $60.4 \mathrm{a}$ & $6.15 \mathrm{a}$ \\
\hline
\end{tabular}

Different alphabets mean statistical difference at the $5 \%$ level. 


\section{CONCLUSIONS}

The extracts from Japanese cypress obtained by squeezing and boiling methods were tested on the storage of litchi fruits at room temperature. The results showed that development of mold on the litchi pericarp surface was slightly inhibited by the treatment with the Japanese cypress extract. The inhibiting effect of the Japanese cypress extract was weaker than that of the chemical storage agent of 45\% Sportak, and comparison on the extraction method from Japanese cypress indicated that the squeezing method was more effective than the boiling methods. However, browning of litchi pericarp was not effectively delayed by the treatment with the Japanese cypress extract irrespective of the extraction method. The content of components controlling the taste of litchi fruits was also not affected by the treatment with the Japanese cypress extract.

\section{ACKNOLEDGEMENTS}

The present research was financially supported by the education fund provided by Education Government of Guangxi Province. The authors express their sincere thanks to them for the financial support.

\section{REFERENCES}

Chen, R 2005 The developing of litchi storage techniques under room temperature and its mechanism. Journal of Anhui Agriculture Science, 6: 1099-1100 (in Chinese)

Chen, W. -H., F. -P. Zhang, J. -X. Lin, B. -C. Ye and M. -L. Yu 2004 Effects of bagging with micro-adjustment of air composition on the quality and some physiological indices of litchi fruit under ambient temperature. Journal of Fruit Science, 1: 85-87 (in Chinese)

Dong, Z. -Y., J. -W. Chi, G. -M. Yang and X. -J. Tang 2005 The health effect and exploitation prospect of litchi. Food Research and Development, 5: 148-151 (in Chinese)

Hu, W. -R., Z. -Q. Zhang, Z. -L. Ji, S. -Z. Liu and H. -L. Zhang 2004 Changes of pericarp color and the content of anthocyanin and flavonoids in litchi pericarp during chilling-injured temperature storage. Acta Horticulture Sinica, 6: 723-726 (in Chinese)
Hu, X. -Y. and Z. -X. Ning 2001 The study and development of the fresh-keeping of litchi. Food and Fermentation Industries, 4: 47-52 (in Chinese)

Lai, Q. -Y. and N. -J. Ao 1998 The developing storage on physiological characteristics of litchi. Yunnan Tropical Science \& Technology, $\mathbf{3}: 27-31$

Liang, H. -H., Z. -L. Ji and X. -Y. Huang 1998 Study on the techniques of package and storage for litchi fruit stored in the room temperature. Journal of Fruit Science, 2: 158163 (in Chinese)

Liu, A. -R., Y. Tian, L. -F. Chen and X. -H. Zhe 1995 Comparison with the functions of styptic and inhibition to mould with Japanese cypress in Shandong Province. Journal of Shangdong College of Traditional Chinese Medicine, 1: 47-49 (in Chinese)

Lu, X. -M 1998 The stored status and developing of litchi processing industry. Fujian Fruits, 1: 19-22 (in Chinese)

Pang, X. -Q. and S. -Q. Zhang 2001 The prevention mechanism of techniques against browning on litchi pericarp. Food Science, 1: 94-97 (in Chinese)

Tang, Z. -P., G. -D. Liang, H. -Y. Li and L. Yan 2006 The developing status and the ways of solution with fruits industry in Guangxi Province. Guangxi Horticulture, 3: 16-18 (in Chinese)

Tian,Y. -J., X. -F. Lin and Y. Liu 2006 Study on the fresh-keeping of litchi fruit stored in room temperature. Chinese Agricultural Science Bulletin, 9: 76-80 (in Chinese)

Wang, L.-S. 1983 The Mechanism and Application of Chinese Herbs. Renmin Healthy Publisher, Beijing (China), 691pp. (in Chinese)

Wu, H. -H., X. -H. Li and L. Qiu 2004 Study on the active free radical of oxygen on litchi and longan fruits. Food Science, 5: 166-169 (in Chinese)

Xie, J. -H., J. Pang, J. -H. Zheng, S. -Q. Zhou, Y. -X. Li and Q. -X. Lin 2001 The effect of solid storage agent to litchi under room temperature. The Development of Agricultural Products, 4: 15-17 (in Chinese)

Xie, L. -L. 2007 The technologies of storage for litchi. World Tropical Agricultural Information, 5: 29-30 (in Chinese)

Xu, X. -C., W. -X. Chen and C. -P. Lin 2005 Study on the changes of physiological characteristics on three varieties of litchi like 'Nomichi' etc. South China Fruits, 4: 22-25 (in Chinese)

Xu, X. -C., Z. -X. Wu and W. -X. Chen 2004 The developing study on browning mechanism of litchi. Storage and Process, 1: 8-10 (in Chinese)

Zhang, X. -M., L. -Q. Du and J. -H. Xie 2004 The developing study of litchi storage after harvesting. South China Fruits, 5: 53-55, 57 (in Chinese) 
